\title{
HISTORIIKKI SUOMEN AKATEMIASTA
}

\begin{abstract}
Jaakko Paavolainen, Linkomiehen komiteasta uuteen Akatemiaan, valtion tieteellisten toimikuntien 60-luku, Suomen Akatemia 1975, $220 \mathrm{~s}$.
\end{abstract}

Suomen Akatemia on teettänyt historioitsija Jaakko Paavolaisella itsestään historiikin, joka rajoittuu käsittelemään 60-luvun tiedepolitiikkaa. Teos tavallaan jatkaa siitä, mihin Pertti Pesosen kirja "Tiede ja opetusministeriö" päättyi. Pesosen kirjassa selvitettiin mm. toimikuntien 50-lukua. Mikäli Akatemian historian teettäjät saavat asiasta päättää on ilmeisesti joskus 1980-luvun puolivälissä odotettavissa- historiikki Akatemian 70-luvusta, sillä Paavolaisen teos ei ajallisen rajauksensa vuoksi puutu viime vuosien tiedepolitiikasta käytyyn keskusteluun, vaan keskittyy historiallisen etäisyyden turvallisemmaksi tekemään 60-lukuun. Mutta kuten Paavolaisen tutkimuksestakin käy ilmi, luotiin nykyinen tiedepoliittinen asetelma paljolti jo viime vuosikymmenellä, joten teos tarjoaa kiinnostavaa taustatietoa myös 70-luvun tiedepolitiikan ymmärtämiseksi.

Kuten Paavolaisen teoksen nimestäkin ilmenee, on hän pyrkinyt samassa tutkimuksessa kirjoittamaan sekä valtiollisen tiedepolitiikan että toimikuntien toiminnan historian. Edellisessä Paavolainen on onnistunut paremmin kuin jälkiminääisessä. Toimikuntien työstä Paavolainen ei saa irti juuri muuta kuin vuosikertomusten yhdistelmien tyyppisiä tietoja toimikuntien jäsenistä, toimien lukumäärästä, määrärahojen kehityksestä jne. 60-luvun tiedepolitiikan kartoitus on huomattavasti mielenkiintoisempi: Paavolainen esittää varsin seikkaperäisen kuvauksen vuosikymmenen tiedepoliittisista tapahtumista, komiteoista, keskusteluista, lainsäädännöstä jne. Teok- sen rajaaminen juhlakirjan tapaan täyteen vuosikymmeneen ei ole sattumalta? - täysin mielivaltainen: vuosikymmenen lopussa toteutuu sen alussa vireille pantu tiedepoliittinen murros. Paavolainen varoo tekemästä laajempia tulkintoja. Tutkimuksen anti onkin lähinnä siinä, että se sisältää runsaasti kiinnostavaa tutkimusaineistoa - sekä tiedepoliittisia juoruja asiantuntijoista asiantuntijoille.

Tiedepoliittisista uudistuksista ja tapahtumista ei 60-luvulla ollut pulaa. Tärkeimmät tiedepoliittiset tapahtumat olivat vuosikymmenen alussa Linkomiehen komitean alullepanẹma toimikuntajärjestelmän uudistaminen ja vuosikymmenen päättävä "uuden akatemian" synty ja "vanhan" lakkauttaminen. Tällä toimenpiteellä lakkautettiin akateemikkojen virat ja toimikunnista tehtiin opetusministerin tiedepoliittisia elimiä (toimikuntien "politisoiminen"). Näiden uudistusten väliin mahtuvat $\mathrm{mm}$. vuoden 1964 tieteellisen tutkimuksen organisaatiokomitean mietintö ja Ketosen komitean laatima korkeakoulujen kehittämisohjelma vuosikymmenen puolivälissä. Vuosikymmenen aikana tieteellisten toimikuntien merkitys tutkimuksen tukijoina kasvaa määrärahojen ja toimien lisääntymisen seurauksena. Vuosikymmenen jälkipuolta sävyttää ajøittain kiivas. väittely "vanhan akatemian" lakkauttamisesta.

60-luvun loppuun mennessä oli luotu tärkeimmät nykyiset tiedepoliittiset ohjelmointi- ja sääntelyelimet: Tiedeneuvosto ja valtion tieteellisten toimikuntien järjestelmä.

Vähintään yhtä kiinnostavaa kuin se, mitä tehtiin, on kuitenkin se mitä ei tehty tai ei kyetty tekemään - ja kuka teki tai jätti tekemättä. Jos vertaa vuosikymmenen saavutuksia niihin ajatuk- siin, joita vuosikymmenen alussa Linkomiehen komitea esitti, voi yhtyä Paavolaisen varovaiseen arvioon, että tällöin ainakin yleispiirteissään hahmoteltu uudistusohjelma ei ollut vuosikymmenen loppuun mennessä toteutunut: "Asiaa kokonaisvaltaisesti tarkasteltaessa huomaa kuitenkin, etteivät valtion tieteelliset toimikunnat 60-luvun Suomessa voineet valtiovallan näkökulmasta olla enempää kuin osa tieteenharjoituksen kokonaiskentässä sitäkin suuremmalla syyllä, kun vain suhteellisen harvat tieteen edustajat halusivat nähdä toimikuntajärjestelmää sellaisena kaiken yläpuolella olevana katto-organisaationa kuin miksi Linkomies ainakin eräässä vaiheessa oli sitä ajatellut." (s. 158)

Paavolaisen tutkimuksen perusteella voisi esittää väitteen, että ne tiedepolitiikan ristiriidat, jotka heiluttavat nykyistä Suomen Akatemiaa, esiintyivät jo Linkomiehen komiteassa ja ne näkyvät komitean ehdotusten saamassa vastaanotossa. Itse asiassa nämä ristiriidat aíheuttivat komitean työn keskeytymisen. Linkomiehen suunnitelma oli luoda keskitetty valtiollinen tiedehallinto. Linkomiehen komiteassa tuotiin esille myös ajatuksia tutkimuksen ja tieteen merkityksestä taloudellisen kasvun ja kilpailukyvyn turvaajana. Komitean työ jäi kesken koska sekä yliopistojen että tutkimuslaitosten edustajat vastustivat sitä. Linkomies itsekin istui oikeastaan kahdella pallilla: olihan hän vanha yliopistomies. Vaikka Linkomiehen komitean piirissä syntyneet ajatukset olivat monessa suhteessa varsin hapuilevia ja vaikka vuosikymmenen kuluessa keskusteluun tuli uusiakin teemoja (projektitutkimus, tavoitetutkimus), voi 60-luvun katsoa silti paljolti merkinneen näiden ajatusten hidasta ja vain osittaista toteutumista. 
60-lukua voi pitää valtiollisen keskitetyn tieteen sääntelyn ja ohjelmoinnin esiinzousun kautena. Tätä kehitystä vastustivat sekä tutkimuslaitosten edustajat, joiden voi tulkita edustavan yksityisten monopolien etuja, että taantumukselliset yliopistomiehet, AKS:n kansallisen tieteen perinteen vaalijat. Tiedepolitiikan kehitys Suomessa on hyvä esimerkki valtiomonopolistisen sääntelyn ristiriitaisesta kehityksestä: "yleinen etu" voi toteutua vain yksityisten etujen ristiriitaisen vaikutuksen ja paineen alaisena. 60-luvun tiedepolitiikan uudistuslinjan "kantajat" olivat toisaalta presidentti Kekkosen valikoimia vanhoja yliopistomiehiä (Linkomies erityisesti, muita mm. Vilkuna ja Ketonen; Paavolainen puhuu "presidentin miehistä"), jotka kantoivat uuden ja vanhan ristiriitaa sisällään, ja toisaalta lähinnä luonnontieteitä edustavia kehittyneiden kapitalistimaiden tiedepolitiikasta mallinsa hakeneita tutkijoita (mm. professorit Hela, Granö ja Gyllenberg). "Presidentin miehistä" ja uusissa teknokraateissa, jotka asettuivat ajamaan uutta valtiollista tiedepolitiikkaa, yhdistyy kaksi sukupolvea. Sukupolven vaihdos tapahtui kyllä synnytystuskien kautta, mutta ilman merkittävää murrosta tai katkosta. Uusi Akatemia on sekoitus uutta ja vanhaa ja sitä vartioivat uuden tiedepolitiikan molemmat kummit: vanhan taantumuksen ja yksityisen pääoman edustajat.

Jukka Gronow
Elinkeinoelämän

(EVA), vuonna 1974 perustettu liike-elämän järjestöjen yhteistyöorganisaatio, järjesti 8. 11. 1976 Felsingissä neuvottelukokouksen "Minne menet markkinatalous?". Kokouksen jälkeenjääneet asiakirjat ovat myös maamme tutkimuksen kannalta siksi mielenkiintoisia, että ne ansaitsevat tarkastelua, vaikka papereiden kulmassa lukeekin "ei julkisuuteen".

Neuvottelukokouksen tavoitteena oli avaajan, pääjohtaja Mika Tiivolan, mukaan hahmotella elinkeinoelämän yhteistä strategista toimintaohjelmaa niistä peruslinjoista, joita olisi noudatettava siirryttäessä 1980-luvulle. Tiivolan omin sanoin: "Elinkeinoelämän piirissä tunnetaan laajjasti huolestumista kehityksen suunnan johdosta ja tarvetta uusien toimintalinjojèn kehittämiseen." Tätä varten EVA:n piirissä on käynnistetty projekti "Minne menet markkinatalous?", jonka toteuttamisesta marraskuun neuvottelukokous oli osa.

Kokoukselle oli EVA:n toimistossa tehty taustaselvitys, jonka osia ovat tilanneanalyysi, johtopäätökset sekä toimintalinjat. Toimintalinja-osasto käsittää seuraavat jaksot: (1) ideologinen keskustelu, (2) elinkeinoelämän sisäiset suhtøet, (3) viestintä, (4) koulutus ja tutkimus ja (5) muut toimenpiteet. Toimintalinja koulutuksen ja tutkimuksen suhteen on hyvin yksiviivainen: "On tuettava niiden järjestöjen toimintaa, jotka pyrkivät vaikuttamaan opetustoiminnan sisältöön." Korkeakoulumaailman osalta viittauksen suunta on selvä, sen päästä löytyy Korkeakoulu- ja tiedepoliittinen tutkimussäätiö, KTTS.

Erityistä mielenkiintoa EVA tuntee tiedotusopin -opetusta kohtaan: taustaselvityksen mukaan "taistelu vallasta yhteiskunnassa on taistelua tiedotusvälineiden hallinnasta". EVA:an ryhmittyneitä voimia huolestuttaa se, että elinkeinoelämän ote tiedotusopin opetuksen sisältöön on liian vähäinen. Tämä ilmaistaan sen enempää pezustelematta seuraavasti: "Opetuksen yksipuolisuus Tampereella on yleisesti tunnustettu tosiasia... Elinkeinoelämän etujen mukaista olisi saada aikaan nykyistä parempi tasapaino tiedotusopin opetuksessa."

Mielenkiintoa herättää neuvottelukokouksen asiakirjoissa mainittu suunnitelma talouspolitiikan johtamisharjoitusten käynnistämisestä. "Harjoitusten organisaation mallina ovat totaalisen maanpuolustuksen kurssit." Johtamisharjoitusten suunnittelussa on EVA:lla ollut avustajinaan : myös maamme tieteen huomattavia -nimiä: Ajatuksen isäksi mainitaan SITRA:n ja Liikkeenjohdon instituutin johtamiskoulutusta selvittänyt toimikunta, jonka puheenjohtajana toimi Helsingin kauppakorkeakoulun rehtori, prof. Jaakko Honko. Johtamisharjoitukset on tarkoitus aloittaa koetilaisuudella vuoden 1977 huhti-toukokuussa, koetilaisuuden rehtoriksi on lupautunut SITRA:n yliasiamies, Teknillisen korkeakoulun teollisuustalouden professori C. E. Carlson. Asiakirjoissa mainitaan edelleen, että johtamisharjoituksista on käyty jo keskusteluja mm. Valtiovarainministeriöm, Suomen Pankin, SIFRA :n, Liikkeenjohdon instituutin, SAK:n ja elinkeinoelämän järjestöjen kanssa. "Asiaan on yleisesti suhtauduttu mÿ̈̈nteisesti."

On epẩilemättä mielenkiintoista tietää, että elinkeinoelämän sisäiseksi johtamiskoulutukseksi ja linjanvedoksi suunnitellaan "totaalisen maanpuolustuksen mallin" mukaan harjoituksia valtion budjettivaroin - SITRA han on kokonaan! valtion rahoittama ja : Liik- 